\title{
SINTESIS PARTIKEL NANO TITANIUM DIOKSIDA PADA KAIN KATUN DAN APLIKASINYA SEBAGAI MATERIAL SELF-CLEANING
}

\author{
Diana Rakhmawaty Eddy*, Mastuti Widi Lestari, Iwan Hastiawan, Atiek Rostika Noviyanti \\ Departemen Kimia, Fakultas Matematika dan Ilmu Pengetahuan Alam, Universitas Padjadjaran, Jln. Raya \\ Bandung- Sumedang km. 21 Jatinangor, Sumedang 43563 \\ *Alamat Korespondensi: diana.rahmawati@unpad.ac.id
}

\begin{abstract}
Abstrak: Katun merupakan salah satu serat alami yang sering digunakan sebagai bahan pakaian. Namun sebagian besar orang-orang sangat sibuk dengan pekerjaan dan tidak mempunyai waktu untuk membersihkan pakaiannya sehari-hari. Maka dari itu perlu dilakukan pengembangan sifat kain katun yang dapat mendekomposisi sendiri kotoran yang mengenainya, atau self-cleaning. Partikel nano $\mathrm{TiO}_{2}$ dengan sifat fotokatalitiknya mampu memberikan sifat self-cleaning pada kain katun. Sintesis partikel nano $\mathrm{TiO}_{2}$ pada kain katun dilakukan dengan metode sonokimia. Titanium Tetraisopropoksida (TTIP) digunakan sebagai prekursor partikel nano $\mathrm{TiO}_{2}$. Dalam penelitian ini dilakukan variasi konsentrasi TTIP dengan cara memvariasikan volume penambahan TTIP $(0,1 ; 1 ; 2 ; 3,1$; dan $4,2 \mathrm{~mL})$ untuk mengetahui pengaruhnya terhadap pengembanan partikel nano $\mathrm{TiO}_{2}$ pada kain katun dan aktivitas self-cleaning-nya. Katun- $\mathrm{TiO}_{2}$ terbukti mempunyai aktivitas selfcleaning yang dapat menghilangkan sendiri noda Rhodamin B baik dengan bantuan sinar matahari maupun lampu UV. Katun- $\mathrm{TiO}_{2} 2$ (volume TTIP $2 \mathrm{~mL}$ ) mempunyai aktivitas menurunkan konsentrasi larutan Rhodamin B terbaik, yaitu sebesar $96,932 \%$ pada lampu UV dan 32,890\% pada tempat gelap. Sedangkan kain katun blanko hanya menurunkan konsentrasi larutan Rhodamin B sebesar 8,647\% pada radiasi lampu UV dan 2,800\% pada tempat gelap. Berdasarkan analisis SEM diketahui bahwa partikel nano telah terdistribusi pada permukaan kain katun walaupun masih terdapat agregrat di beberapa bagian. Analisis XRD menunjukkan bahwa partikel nano $\mathrm{TiO}_{2}$ baik yang terbentuk pada kain katun maupun dalam bentuk padatan mempunyai fase anatase dengan ukuran kristal 14,05 $\mathrm{nm}$.
\end{abstract}

Kata kunci: partikel nano $\mathrm{TiO}_{2}$, sonokimia, tekstil, katun, self-cleaning, fotokatalitik

Abstract: Cotton is a natural fiber that often used as a clothing material. Yet most people are so busy with work and do not have time to clean clothes everyday. Thus it is necessary for developing cotton fabric's properties that can decompose its own dirt, or named "self-cleaning". $\mathrm{TiO}_{2}$ nanoparticles with photocatalytic properties are able to provide "self-cleaning" on cotton fabrics. TiO $\mathrm{O}_{2}$ nanoparticles on cotton fabrics were synthesized using sonochemical method. Titanium Tetraisopropoxide (TTIP) is used as a precursor of TiO ${ }_{2}$ nanoparticles. In this research, varying volume of TTIP additions $(0.1 ; 1 ; 2 ; 3.1$; and $4.2 \mathrm{~mL})$ to determine its impact on developing of $\mathrm{TiO}_{2}$ nanoparticles on cotton fabric and the activity of self-cleaning. Cotton-TiO ${ }_{2}$ have selfcleaning activity which can remove Rhodamine B stain and fade ink stain under radiation both sunlight and $U V$ lamp. Cotton-TiO 2 (TTIP volume: $2 \mathrm{~mL}$ ) has an activity lowering the concentration Rhodamine B solution, which amounted to $96.932 \%$ of the UV lamp and $32.890 \%$ in the dark place. While cotton blank just lowering concentration of $8.647 \%$ Rhodamine B under radiation UV lamp and 2,800\% in the dark place. Based on SEM analysis is known that nanoparticles have been distributed on the surface of cotton cloth although still have aggregate. XRD analysis showed that both $\mathrm{TiO}_{2}$ nanoparticle formed in cotton cloth and solid as anatase phase and has a crystal size $14.05 \mathrm{~nm}$.

Keywords: $\mathrm{TiO}_{2}$ nanoparticles, sonochemical, textile, cotton, self-cleaning, photocatalytic

\section{PENDAHULUAN}

Katun merupakan salah satu serat alami yang sering digunakan sebagai bahan pakaian. Kain katun mempunyai karakteristik yang baik untuk pakaian karena dapat diregenasi, biodegradabel, lembut, nyaman, hangat, dan higroskopis. Namun, sebagian besar orang-orang sangat sibuk dengan pekerjaan dan tidak mempunyai waktu untuk membersihkan pakaiannya sehari-hari. Pencucian dan produk disinfektan mengandung bahan kimia, seperti agen bleaching dan alkohol. Kontak pada bahan kimia tersebut dapat membahayakan kesehatan dan hanya dapat membersihkan dalam jangka pendek.

Pengembangan sifat tekstil dibutuhkan untuk mengatasi masalah di atas. Tekstil diharapkan dapat mendekomposisi sendiri kotoran yang mengenainya. Sifat ini dinamakan "self-cleaning". Sifat selfcleaning pada permukaan tekstil bekerja saat permukaan mendapat radiasi sinar ultraviolet (UV) sehingga terjadi reaksi fotokatalitik. Reaksi fotokatalitik ini melibatkan foton dari cahaya yang menyerang permukaan material self-cleaning, dan menyebabkan terbentuknya radikal superoksida $\left(\bullet \mathrm{O}_{2}\right)$ dan/atau hidroksil $(\bullet \mathrm{OH})$. Radikal ini akan menyerang spesies organik yang teradsorpsi pada permukaan dan mendegradasinya. Partikel nano $\mathrm{TiO}_{2}$ mempunyai sifat fotokatalitik sehingga dapat memberikan sifat self-cleaning pada tekstil. 
Pengembangan metode sintesis partikel nano $\mathrm{TiO}_{2}$ sangat diperlukan untuk mengendalikan fase kristal, ukuran, dan morfologi nanokristal $\mathrm{TiO}_{2}$. Beberapa metode telah digunakan untuk preparasi partikel nano $\mathrm{TiO}_{2}$, seperti co-presipitasi, sol-gel, electrospinning, hidrotermal, dan sonokimia. Pengontrolan struktur kristal, ukuran, dan morfologi partikel nano $\mathrm{TiO}_{2}$ dapat dilakukan dengan metode sonokimia. Metode sonokimia merupakan metode sintesis partikel nano dengan memanfaatkan gelombang ultrasonik. Keuntungan metode sonokimia untuk sintesis partikel nano logam oksida antara lain distribusi ukuran partikel yang seragam, luas permukaan yang besar, waktu reaksi yang cepat, dan meningkatkan kemurnian fase. Dalam sintesis partikel nano, metode sonokimia dipengaruhi oleh suhu sonikasi, lama radiasi, komposisi larutan (misalnya perbandingan mol air, alkohol, dan prekursor), $\mathrm{pH}$ larutan, dan jenis agen pendispersi.

Penelitian ini bertujuan untuk menyintesis partikel nano $\mathrm{TiO}_{2}$ pada kain katun menggunakan metode sonokimia. Variasi konsentrasi prekursor dilakukan untuk mengetahui massa optimum partikel nano $\mathrm{TiO}_{2}$ yang teremban pada kain katun, dan pengaruhnya terhadap aktivitas self-cleaning. Titanium Tetraisopropoksida (TTIP) dipilih sebagai prekursor $\mathrm{TiO}_{2}$. Variasi konsentrasi TTIP dilakukan dengan memvariasikan volume TTIP, yaitu 0,$1 ; 1 ; 2$; 3,$1 ; 4,2 \mathrm{~mL}$. Selain itu, dilakukan pembandingan aktivitas self-cleaning pada radiasi terkontrol (lampu UV) dan sinar matahari.

\section{BAHAN DAN METODE Alat dan Bahan}

Peralatan yang digunakan dalam penelitian ini meliputi peralatan gelas, buret dan klem, magnetic stirrer hotplate (Heidolph, D91126 MR-Hei Standart), neraca analitis (Mettler Toledo, AB164-S), oven (Carbolite S30 2RR, PN 60), alat ultrasonikasi (S 60 H Elmasonic), seperangkat alat uji fotokatalitik dilengkapi lampu UV (Philips HPL-N125W), Centrifuge (Beckman TJ-6 with TJ-R Refrigeration Unit), Spektrofotometer UV-Vis (Thermo Scientific, Genesys 10S), XRD (PANalytical X'Pert High Score), dan SEM-EDS (Tabletop TM 3000, Hitachi).

Bahan kimia yang digunakan adalah kain katun 100\% berwarna putih, Titanium Tetraisopropoksida (TTIP) 97\% (Sigma-Aldrich), Asam Asetat Glasial (Merck), Etanol 96\% (Merck), Aqua bidestilasi, Zat Warna Rodhamin B (RB), dan detergen non-ionik dengan bahan aktif alkohol etoksilat $12 \%$ (Cussons baby Stain Remover).

\section{Pencucian kain katun}

Pencucian kain katun diadopsi dari prosedur yang telah dilakukan oleh Sadr \& Montazer (2014). Kain katun ukuran $5 \times 5 \mathrm{~cm}^{2}$ sebanyak empat lembar dicuci dalam larutan deterjen non-ionik dengan komposisi 2 $\mathrm{mL}$ deterjen dan $40 \mathrm{~mL}$ aquades. Kain katun dicuci pada suhu $60^{\circ} \mathrm{C}$ selama 15 menit. Kain katun dibilas dengan aquabides kemudian dikeringkan pada suhu $70^{\circ} \mathrm{C}$ selama 1 jam. Kain katun yang telah bersih dan kering ditimbang untuk mengetahui berat awal sebelum penambahan partikel nano $\mathrm{TiO}_{2}$.

\section{Sintesis partikel nano $\mathrm{TiO} 2$ pada kain katun menggunakan metode sonokimia}

Pada sintesis ini, $50 \mathrm{~mL}$ aquabides dicampur dengan 0,2 $\mathrm{mL}$ asam asetat glasial, sambil diaduk pada magnetic-stirrer selama 5 menit. Sepotong kain katun $5 \times 5 \mathrm{~cm}^{2}$ dibenamkan dalam larutan dan disonikasi pada bath ultrasonik selama 5 menit. Campuran TTIP (dengan variasi volume $0,1 \mathrm{~mL} ; 1$ $\mathrm{mL} ; 2 \mathrm{~mL} ; 3,1 \mathrm{~mL}$; dan $4,2 \mathrm{~mL}$ ) dan $5 \mathrm{~mL}$ etanol ditambahkan dengan cara tetes demi tetes ke dalam larutan kerja selama sonikasi. Campuran disonikasi selama 4 jam dan ketika suhu mencapai $75^{\circ} \mathrm{C}$, dipertahankan sampai akhir reaksi. Kain katun didiamkan selama 24 jam dalam kondisi ambien. Kemudian kain katun dibilas dengan aquabides dan dikeringkan pada suhu $70^{\circ} \mathrm{C}$ selama 1 jam. Untuk mendapatkan serbuk $\mathrm{TiO}_{2}$, campuran yang dihasilkan (tanpa kain katun) disentrifugasi selama 20 menit (7500 rpm) untuk mengendapkan serbuk $\mathrm{TiO}_{2}$. Hasil serbuk dicuci dengan aquabides dan dikeringkan pada suhu $70^{\circ} \mathrm{C}$ selama 18 jam.

\section{Pengujian sifat self-cleaning Katun- $\mathrm{TiO}_{2}$}

Pengujian sifat self-cleaning Katun-TiO $\mathrm{O}_{2}$ terhadap noda $R B$ pada sinar matahari

Pengujian sifat self-cleaning dilakukan dengan membandingkan perbedaan warna noda RB 0,001\% pada kain katun terlapis $\mathrm{TiO}_{2}$ dan tidak terlapis $\mathrm{TiO}_{2}$ (blanko). Lima sampel Katun- $\mathrm{TiO}_{2}$ (dengan volume TTIP 0,$1 ; 1 ; 2 ; 3,1 ; 4,2$ ) dan katun blanko masingmasing diberi setetes RB pada permukaan dengan cara: $\mathrm{RB}$ diteteskan ke permukaan kain menggunakan buret pada ketinggian $1 \mathrm{~cm}$ di atas kain. Sampel bernoda RB dikeringkan pada suhu kamar dan diradiasikan sinar matahari selama 5 jam.

\section{Pengujian sifat self-cleaning $\mathrm{Katun-TiO} \mathrm{O}_{2}$ terhadap noda $\mathrm{RB}$} pada sinar lampu $U V$

Lima sampel Katun- $\mathrm{TiO}_{2}$ (dengan volume TTIP $0,1 ; 1 ; 2 ; 3,1 ; 4,2)$ dan katun blanko masing-masing diberi setetes RB 0,001\% pada permukaan dengan cara: RB diteteskan ke permukaan kain menggunakan buret pada ketinggian $1 \mathrm{~cm}$ di atas kain. Sampel bernoda RB dikeringkan pada suhu kamar dan diradiasikan lampu UV selama 5 jam.

\section{Pengujian fotodegradasi Katun- $\mathrm{TiO}_{2}$ terhadap larutan RB pada sinar lampu UV \\ Lima sampel katun- $\mathrm{TiO}_{2}$ (dengan volume TTIP} 0,$1 ; 1 ; 2 ; 3,1 ; 4,2$ ) dan katun blanko berukuran $2,5 \mathrm{x}$ $2,5 \mathrm{~cm}^{2}$ masing-masing dimasukkan ke dalam tabung reaksi yang berisi $25 \mathrm{~mL}$ larutan $\mathrm{RB} \quad 0,001 \%$. Campuran tersebut diradiasikan lampu UV selama 5 jam disertai pengadukan. Masing-masing campuran disaring dan diuji absorbansinya menggunakan spektrofotometer UV-Vis. Perhitungan persen fotodegradasi dilakukan dengan membandingkan 
absorbansi larutan RB yang diradiasikan lampu UV dan tanpa cahaya (gelap).

\section{Karakterisasi partikel nano $\mathrm{TiO}_{2}$ dan kain terlapis partikel nano $\mathrm{TiO}_{2}$}

Morfologi sampel kain dilihat dengan menggunakan Scanning Electron Microscope (SEM). Komposisi elemen yang terdapat pada sampel kain diteliti dengan Energy Dispersive X-ray Spectroscopy (EDS). $X$-Ray Diffraction (XRD) digunakan untuk mengidentifikasi fase kristal dan struktur yang terbentuk. Pola XRD yang didapat dicocokkan dengan pola standar pada International Crystal Structure Database (ICSD). Ukuran kristal $\mathrm{TiO}_{2}$ dihitung menggunakan persamaan Scherrer:

$$
D=\frac{K \lambda}{B \cos \theta_{B}}
$$

dimana $\mathrm{D}$ adalah ukuran (diameter) kristalin, $\lambda$ adalah panjang gelombang sinar-x yang digunakan, $\theta_{B}$ adalah sudut Bragg, B adalah FWHM satu puncak yang dipilih dan $\mathrm{K}$ adalah konstanta material yang nilainya kurang dari satu. Nilai yang umum dipakai untuk $\mathrm{K} \approx 0,9$.

\section{HASIL DAN PEMBAHASAN}

Sintesis Partikel nano $\mathrm{TiO}_{2}$ Pada Kain Katun Menggunakan Metode Sonokimia

$\mathrm{TiO}_{2}$ yang teremban pada kain katun merupakan selisih dari massa kain katun sebelum dan setelah proses sintesis. Data massa $\mathrm{TiO}_{2}$ pada katun-TiO ditunjukkan pada Tabel 1.

Partikel nano $\mathrm{TiO}_{2}$ diembankan pada kain katun menggunakan radiasi ultrasonik. Sintesis partikel nano $\mathrm{TiO}_{2}$ dimulai dengan mencampurkan akuabides sebagai penghidrolisis, dan asam asetat glasial sebagai agen pendispersi. Sonikasi larutan asam asetat dan kain katun bertujuan untuk memudahkan adsorpsi partikel nano $\mathrm{TiO}_{2}$ pada kain katun. Agen pendispersi berguna agar partikel nano $\mathrm{TiO}_{2}$ yang terbentuk terdispersi sempurna dan stabil pada kain katun. Prekursor TTIP dilarutkan terlebih dahulu menggunakan etanol untuk mengurangi kereaktifan TTIP terhadap air pada saat proses hidrolisis.

Konsentrasi TTIP yang ditambahkan berpengaruh terhadap massa partikel nano $\mathrm{TiO}_{2}$ yang teremban pada kain katun. Semakin besar konsentrasi TTIP semakin besar pula massa $\mathrm{TiO}_{2}$ yang teremban pada kain katun. Berdasarkan Tabel 4.1, terdapat massa $\mathrm{TiO}_{2}$ maksimum yang teremban pada kain katun. Kain katun yang ditambah TTIP sebanyak 3,1 mL memiliki massa $\mathrm{TiO}_{2}$ yang paling banyak diantara variasi volume yang lain. Hal ini menunjukkan, apabila permukaan kain katun sudah jenuh mengikat partikel $\mathrm{TiO}_{2}$, maka partikel $\mathrm{TiO}_{2}$ yang lain tidak akan terikat dan kemudian lepas dalam bentuk padatan $\mathrm{TiO}_{2}$.

Tabel 1. Massa $\mathrm{TiO}_{2}$ pada katun- $-\mathrm{TiO}_{2}$

\begin{tabular}{cccc}
\hline $\begin{array}{c}\text { Volume TTIP } \\
(\mathrm{mL})\end{array}$ & $\begin{array}{c}\text { Massa kain katun } \\
\text { bersih }(\mathrm{g})\end{array}$ & $\begin{array}{c}\text { Massa katun- } \mathrm{TiO}_{2} \\
(\mathrm{~g})\end{array}$ & $\begin{array}{c}\text { Massa } \mathrm{TiO}_{2} \text { pada } \\
\text { kain katun }(\mathrm{g})\end{array}$ \\
\hline 0,1 & 0,497 & 0,529 & 0,032 \\
1 & 0,513 & 0,620 & 0,107 \\
2 & 0,519 & 0,633 & 0,114 \\
3,1 & 0,520 & 0,667 & 0,147 \\
4,2 & 0,514 & 0,626 & 0,112 \\
\hline
\end{tabular}

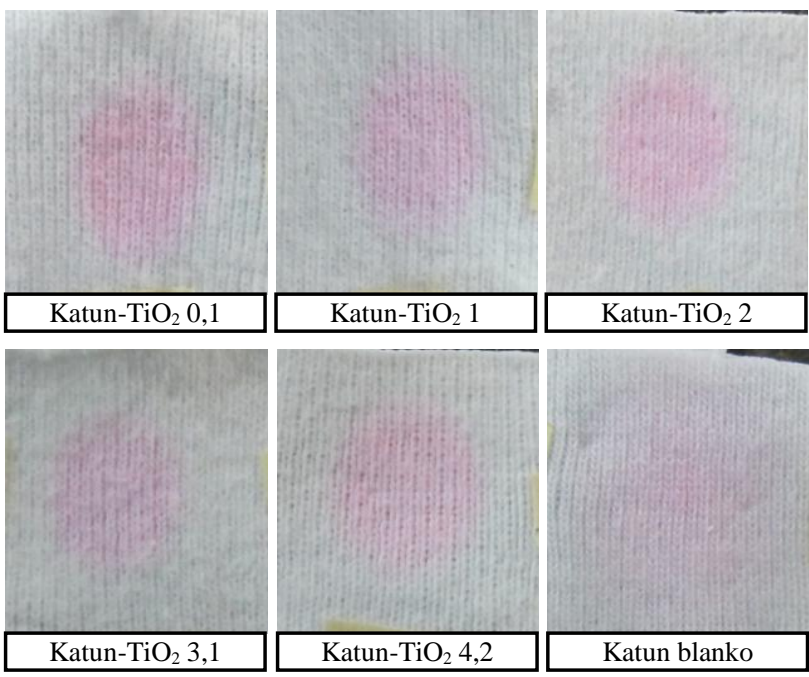

Gambar 1. Katun-TiO2 noda RB sebelum diradiasikan sinar matahari 

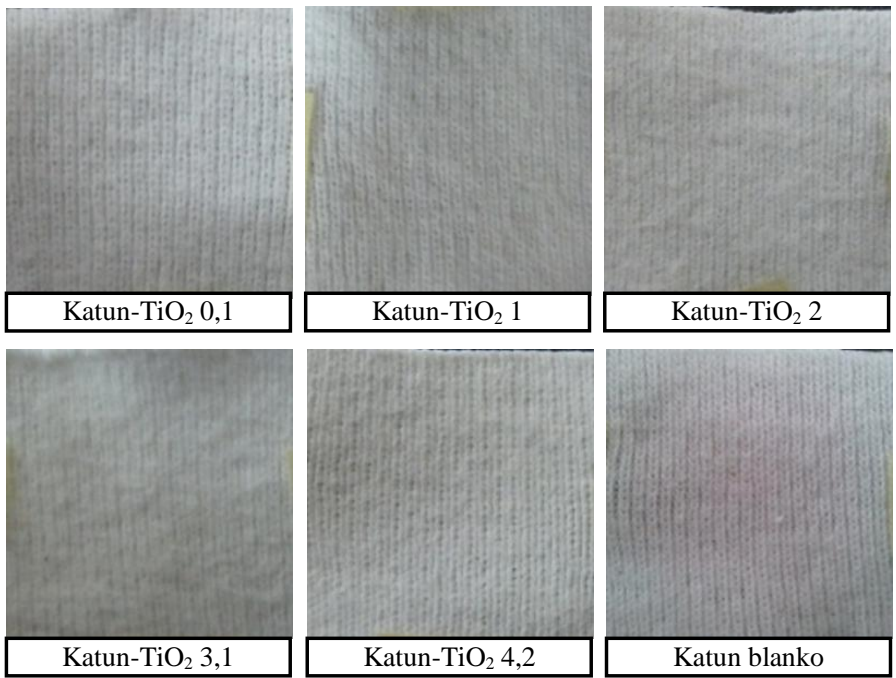

Gambar 2. Katun- $\mathrm{TiO}_{2}$ noda $\mathrm{RB}$ setelah diradiasikan sinar matahari
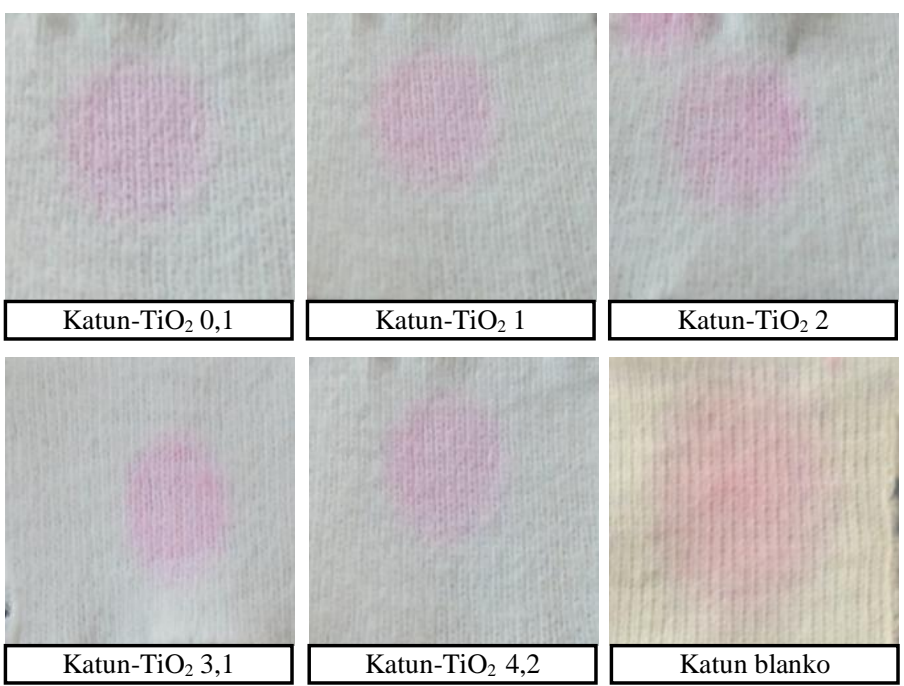

Gambar 3. Katun- $\mathrm{TiO}_{2}$ noda RB sebelum diradiasi lampu UV
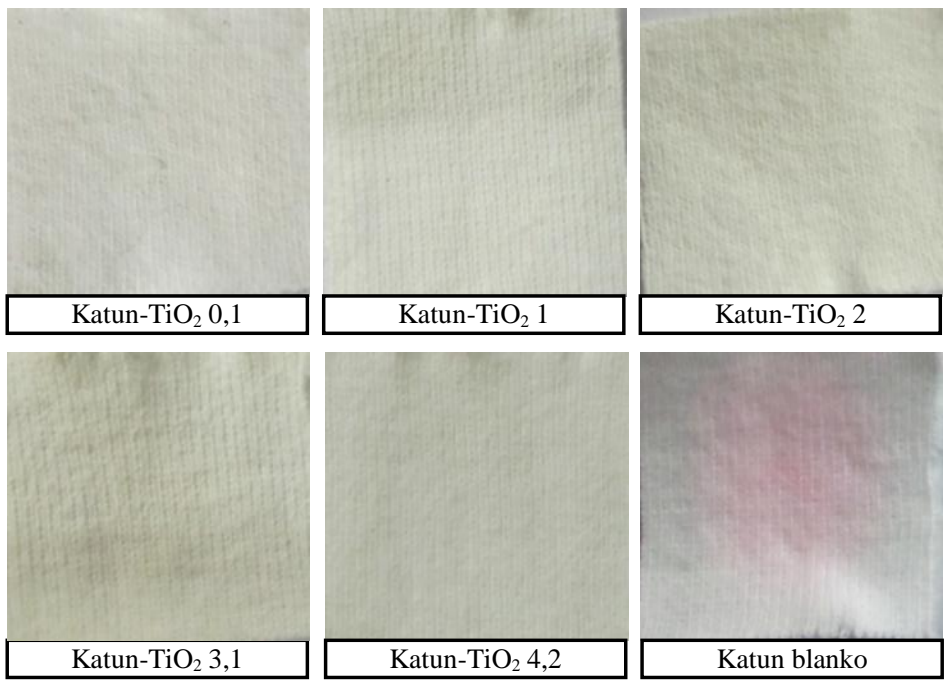

Gambar 4. Katun- $\mathrm{TiO}_{2}$ noda RB setelah diradiasi lampu UV 


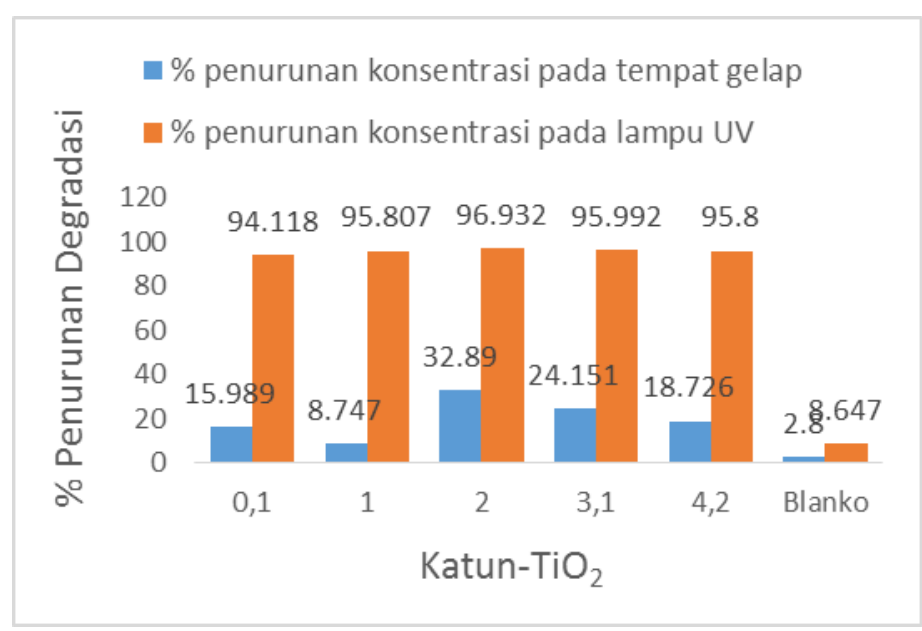

Gambar 5. Persen penurunan konsentrasi larutan $\mathrm{RB}$ oleh katun- $\mathrm{TiO}_{2}$

Pengujian Sifat Self-Cleaning Katun-TiO, Terhadap Noda Rhodamin B (RB) Pada Sinar Matahari

Berdasarkan Gambar 1 dan Gambar 2, katun- $\mathrm{TiO}_{2}$ mampu untuk menghilangkan noda RB yang diteteskan pada permukaan dengan bantuan sinar matahari. Katun- $\mathrm{TiO}_{2}$ dengan massa $\mathrm{TiO}_{2}$ terkecil, yaitu Katun- $\mathrm{TiO}_{2}$ 0,1, mampu untuk menghilangkan noda RB dalam 5 jam. Pada katun blanko terlihat bahwa adanya pemudaran warna pada noda RB.

Hal ini menunjukkan bahwa radiasi sinar matahari dapat memudarkan noda $\mathrm{RB}$ namun tidak menghilangkannya dalam waktu 5 jam.

\section{Pengujian Sifat Self-Cleaning Katun-TiO Terhadap Noda RB Pada Sinar Lampu UV}

Katun- $\mathrm{TiO}_{2}$ mampu menghilangkan noda $\mathrm{RB}$ dengan bantuan radiasi lampu UV. Noda RB pada katun blanko menunjukkan pemudaran warna dari sebelum dan sesudah radiasi lampu UV. Hal ini menunjukkan bahwa radiasi lampu UV mampu untuk memudarkan noda RB namun tidak menghilangkannya dalam waktu 5 jam. Katun- $\mathrm{TiO}_{2}$ terbukti mempunyai sifat self-cleaning noda RB baik pada radiasi sinar matahari dan lampu UV.

Permukaan serat katun yang terlapis partikel nano $\mathrm{TiO}_{2}$ bersifat hidrofobik apabila baru saja dipreparasi. Hal ini menyebabkan noda yang mengenai permukaan katun- $\mathrm{TiO}_{2}$ mempunyai wilayah penyebaran yang lebih sempit dan warna noda yang lebih intens dibandingkan pada kain katun blanko (Qi et al. 2006).

Gambar 3 dan Gambar 4 menunjukkan noda Rhodamin B merata lebih luas pada kain katun blanko. Hal ini disebabkan kain katun blanko lebih bersifat hidrofilik dibandingkan dengan katun- $\mathrm{TiO}_{2}$.

\section{Pengujian Fotodegradasi Katun-TiO $\mathrm{T}_{2}$ terhadap Larutan RB pada Radiasi Lampu UV}

Pengujian fotodegradasi katun- $\mathrm{TiO}_{2}$ terhadap larutan $\mathrm{RB}$ dilakukan untuk mengetahui persen $\mathrm{RB}$ terdegradasi karena kehadiran $\mathrm{TiO}_{2}$ pada kain katun.
Persen degradasi RB dihitung berdasarkan selisih persen penurunan konsentrasi larutan $\mathrm{RB}$ yang disinari lampu UV dan tanpa dikenai cahaya (gelap). Pengujian pada tempat gelap dilakukan untuk mengetahui aktifitas adsorpsi katun- $\mathrm{TiO}_{2}$. Persen penurunan konsentrasi diperoleh melalui persamaan sebagai berikut:

$\%$ penurunan konsentrasi $=\frac{\left(A b s_{\text {awal }}-A b s_{\text {akhir }}\right)}{A b s_{\text {awal }}} .100 \%$

$A b s_{\text {awal }}$ adalah absorbansi awal larutan RB sebelum proses fotodegradasi. $A b s_{a k h i r}$ adalah absorbansi larutan RB setelah proses degradasi. Gambar 5 menunjukkan diagram persen penurunan konsentrasi $\mathrm{RB}$ oleh katun- $\mathrm{TiO}_{2}$.

Pada Gambar 5, ditunjukkan adanya selisih antara penurunan konsentrasi pada radiasi lampu UV dan tempat gelap. Artinya, katun- $\mathrm{TiO}_{2}$ yang disintesis memiliki aktivitas sebagai pendegradasi larutan RB. Pada blanko terlihat bahwa adanya penurunan konsentrasi larutan RB pada tempat gelap. Hal ini menunjukkan bahwa kain katun memiliki aktivitas adsorpsi namun relatif rendah. Selain itu, pada blanko juga terlihat bahwa ada selisih antara persen penurunan konsentrasi pada radiasi lampu UV dan tempat gelap. Hal ini menunjukkan bahwa radiasi lampu UV dapat mendegradasi larutan RB, namun aktivitasnya rendah apabila tidak didukung oleh fotokatalis seperti $\mathrm{TiO}_{2}$.

Katun- $\mathrm{TiO}_{2}$ yang mempunyai massa $\mathrm{TiO}_{2}$ paling besar (katun- $\mathrm{TiO}_{2}$ 3,1) diharapkan mempunyai aktivitas fotodegradasi paling besar untuk larutan RB. Namun, pada Gambar 5, persen degradasi yang tidak linier berdasarkan banyaknya massa $\mathrm{TiO}_{2}$ pada kain katun. Hal ini dikarenakan distribusi partikel $\mathrm{TiO}_{2}$ yang tidak merata pada kain katun. Pada saat sintesis katun- $\mathrm{TiO}_{2}$, kain katun berukuran 5 x $5 \mathrm{~cm}^{2}$. Ketika katun- $\mathrm{TiO}_{2}$ akan digunakan untuk pengujian fotodegradasi larutan $\mathrm{RB}$, katun- $\mathrm{TiO}_{2}$ dipotong menjadi 2,5 x 2,5 $\mathrm{cm}^{2}$. Massa $\mathrm{TiO}_{2}$ yang terdapat pada potongan tersebut kemungkinan berbeda pada potongan bagian lain dalam satu kain. Selain itu, proses pemotongan juga berpengaruh terhadap 


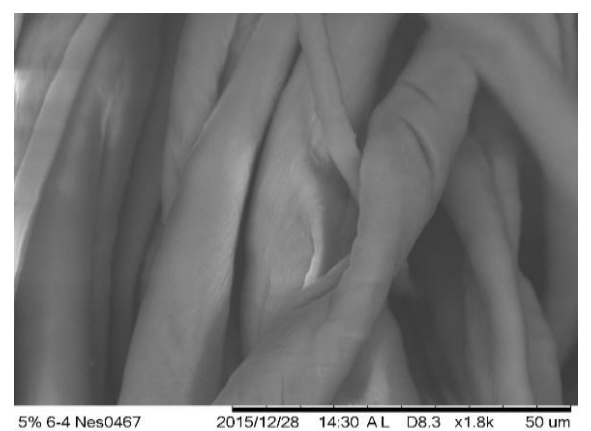

(a)

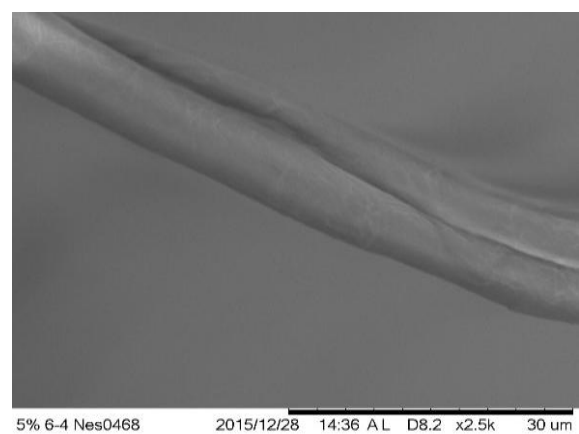

(b)

Gambar 6. Morfologi partikel nano $\mathrm{TiO}_{2}$ pada perbesaran (a) 2.500 kali (b) 4000 kali

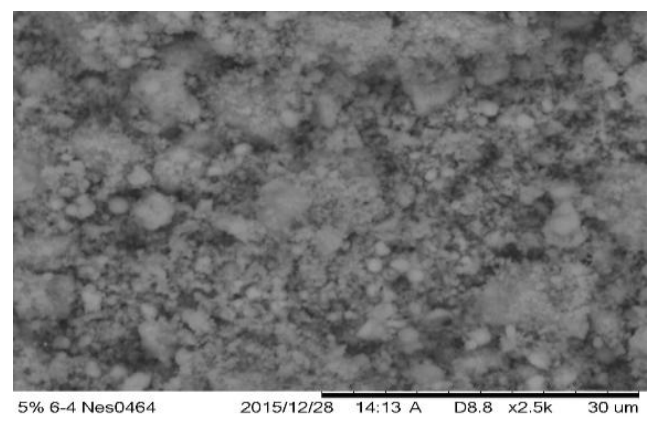

(a)

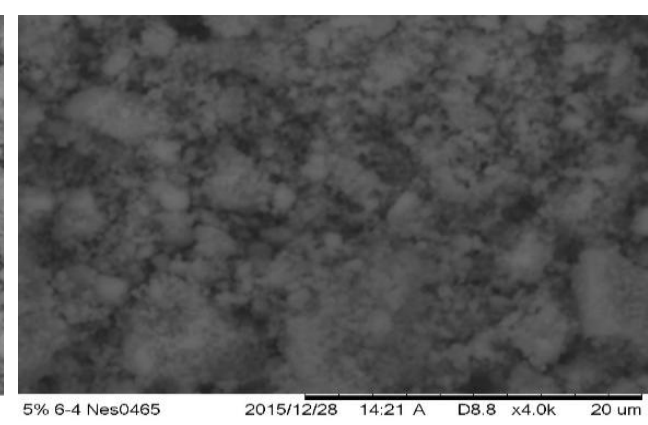

(b)

Gambar 7. Morfologi kain katun blanko pada perbesaran (a) 1800 kali (b) 2500 kali

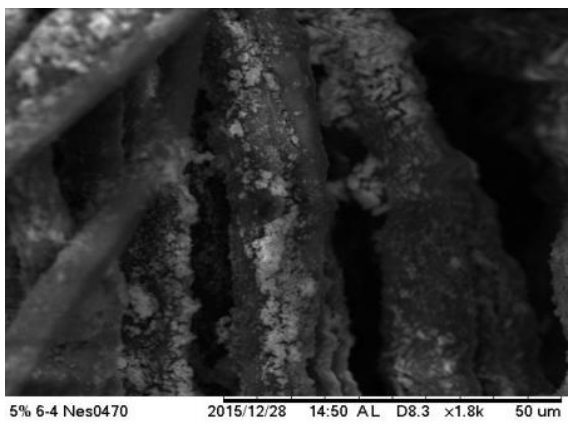

(a)

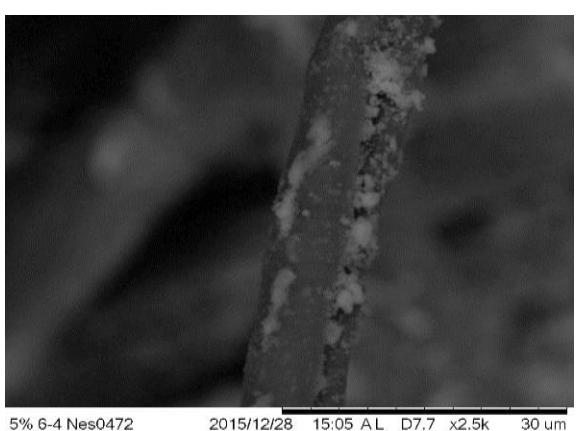

(b)

Gambar 8. Morfologi katun- $\mathrm{TiO}_{2}$ pada perbesaran (a) 1800 kali (b) 2500 kali

berkurangnya massa $\mathrm{TiO}_{2}$ pada kain katun karena adanya tekanan fisik.

\section{Karakterisasi partikel nano $\mathrm{TiO}_{2}$ dan kain terlapis partikel nano $\mathrm{TiO}_{2}$}

Penentuan morfologi partikel nano $\mathrm{TiO}_{2}$ dan katun- $\mathrm{TiO}_{2}$ menggunakan SEM dan komposisinya menggunakan EDS. Hasil karakterisasi partikel nano $\mathrm{TiO}_{2}$ menggunakan SEM ditunjukkan pada Gambar 6.

Pada Gambar 6, morfologi partikel nano $\mathrm{TiO}_{2}$ terlihat tidak merata. Hal ini disebabkan adanya serabut-serabut selulosa dari kain katun yang lepas karena proses sintesis. Morfologi katun- $\mathrm{TiO}_{2}$ dilihat dengan membandingkan morfologi kain katun blanko. Gambar 7 menunjukkan morfologi kain katun blanko, sedangkan Gambar 8 menunjukkan morfologi katun- $\mathrm{TiO}_{2}$.

Pada Gambar 7 dan Gambar 8 terlihat perbedaan antara kain katun sebelum dan setelah ditambah partikel nano $\mathrm{TiO}_{2}$. Permukaan kain katun sebelum ditambah $\mathrm{TiO}_{2}$ terlihat polos dan bersih. Pada Gambar 8 menunjukkan bahwa kain katun telah terlapisi $\mathrm{TiO}_{2}$. Lapisan $\mathrm{TiO}_{2}$ pada kain katun berupa lapisan padat namun belum homogen karena adanya agregasi di beberapa bagian. Wu et al. (2009) dalam Sadr and Montazer (2014) menyatakan bahwa partikel nano $\mathrm{TiO}_{2}$ yang terdeposisi pada permukaan serat katun yang kasar cenderung sukar membentuk 


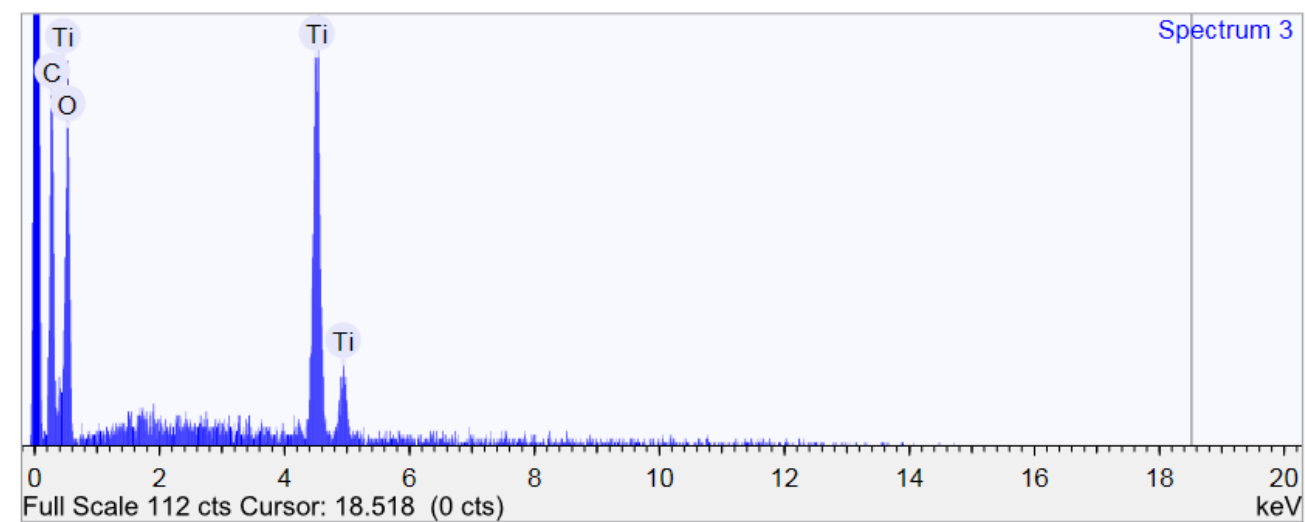

Gambar 9. Spektrum EDS komposisi Katun- $\mathrm{TiO}_{2}$

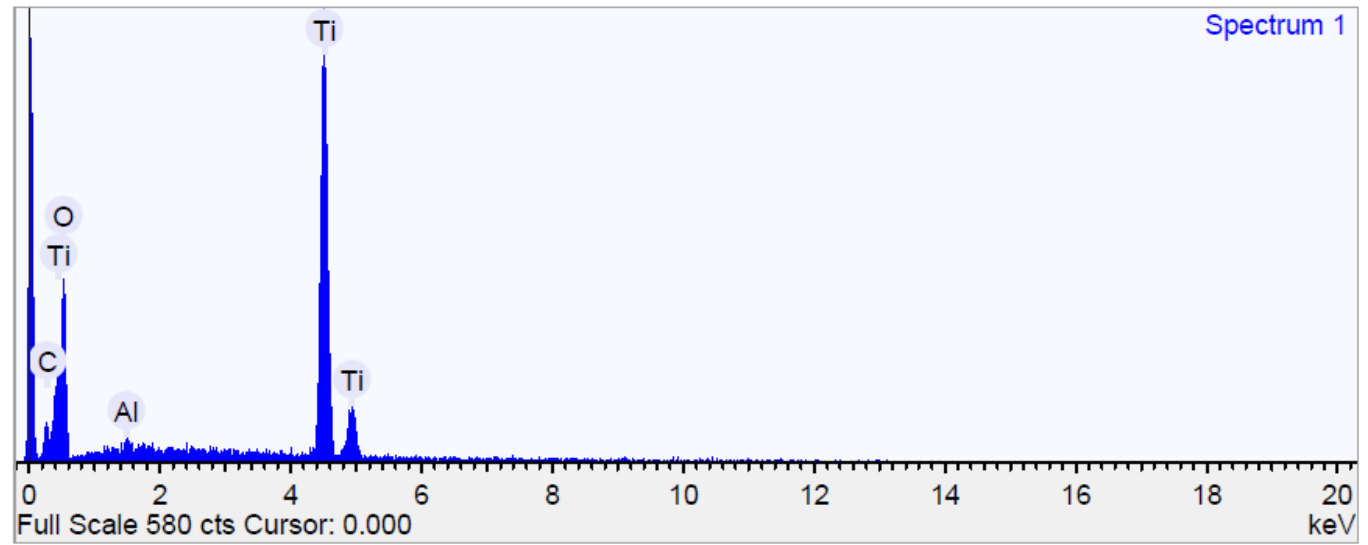

Gambar 10. Spektrum EDS komposisi partikel nano $\mathrm{TiO}_{2}$

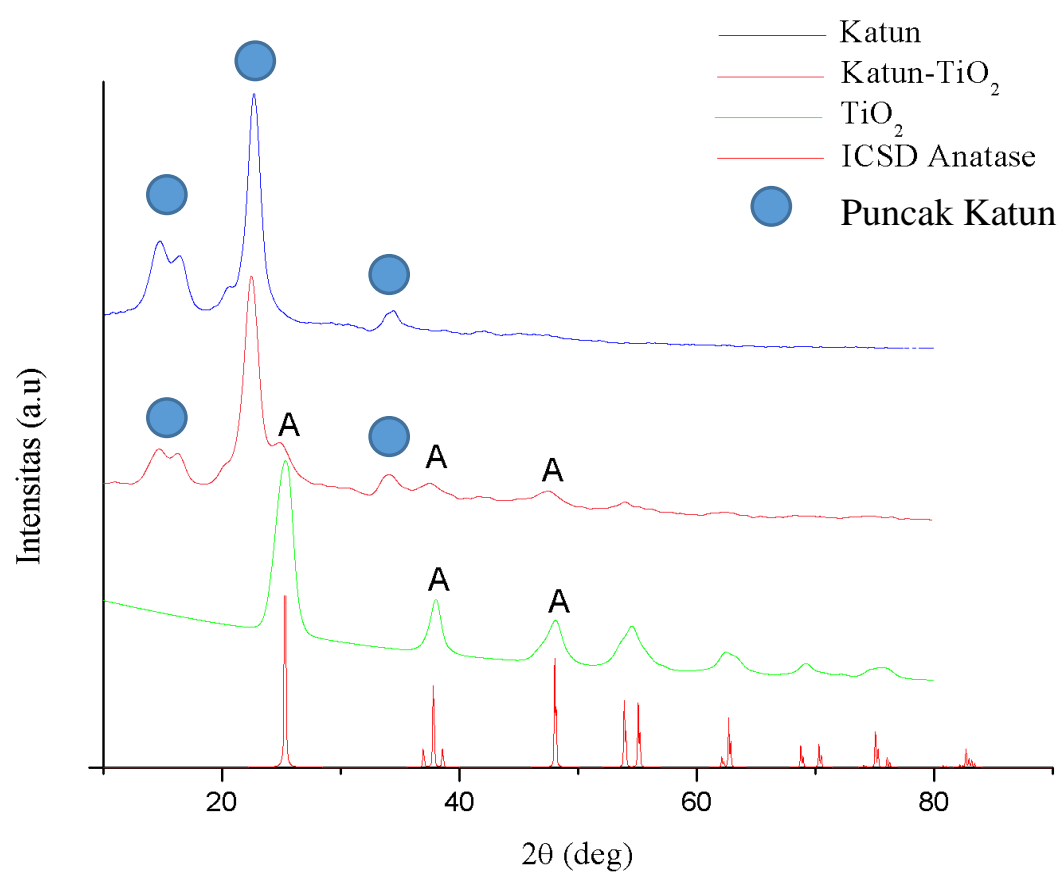

Gambar 11. Difraktogram XRD untuk katun blanko, katun- $\mathrm{TiO}_{2}$ dan $\mathrm{TiO}_{2}$ 
lapisan yang homogen. Agregrasi partikel nano $\mathrm{TiO}_{2}$ lebih mudah terjadi pada permukaan yang kasar dibandingkan pada permukaan yang halus.

Tabel 2. Data EDS komposisi katun- $\mathrm{TiO}_{2}$

\begin{tabular}{ccc}
\hline Unsur & \%Berat & \%Atom \\
\hline Karbon & 26,941 & 38,652 \\
Oksigen & 48,882 & 52,650 \\
Titanium & 24,177 & 8,698 \\
\hline
\end{tabular}

Tabel 3. Data EDS komposisi partikel nano $\mathrm{TiO}_{2}$

\begin{tabular}{ccc}
\hline Unsur & \%Berat & \%Atom \\
\hline Karbon & 5,163 & 9,509 \\
Oksigen & 50,517 & 69,845 \\
Aluminium & 0,501 & 0,411 \\
Titanium & 43,819 & 20,236 \\
\hline
\end{tabular}

Analisis EDS dilakukan pada sampel katun-TiO2 dan partikel nano $\mathrm{TiO}_{2}$. Gambar 9 menunjukkan spektrum komposisi katun- $\mathrm{TiO}_{2}$ dan Tabel 2 menunjukkan data komposisi Katun- $\mathrm{TiO}_{2}$. Gambar 10 menunjukkan spektrum komposisi partikel nano $\mathrm{TiO}_{2}$ dan Tabel 3 menunjukkan data komposisi partikel nano $\mathrm{TiO}_{2}$.

Tabel 2 menunjukkan data komposisi pada Gambar 9. Pada Tabel 2 diketahui bahwa persen atom oksigen sebesar $52,650 \%$. Persen atom yang tinggi tersebut berasal dari atom oksigen pada $\mathrm{TiO}_{2}$ dan selulosa kain katun. Selain itu, persen atom karbon sebesar 38,652\% juga merupakan karbon milik selulosa kain katun dan tape yang digunakan saat analisis EDS

Tabel 3 menunjukkan data komposisi pada Gambar 10. Pada Tabel 3 diketahui bahwa persen atom oksigen sebesar $69,845 \%$ dan atom $\mathrm{Ti}$ sebesar 20,236\% merupakan atom-atom $\mathrm{TiO}_{2}$.

Adanya pengotor aluminium dengan persen atom sebesar $0,411 \%$ dikarenakan aluminium foil yang digunakan untuk menutup reaktor pada saat proses sintesis.

Penentuan fase dan ukuran kristal partikel nano $\mathrm{TiO}_{2}$ dilakukan dengan analisis XRD. Difraktogram partikel nano $\mathrm{TiO}_{2}$, katun- $\mathrm{TiO}_{2}$ dan katun blanko yang dihasilkan dibandingkan dengan standar ICSD nomor $172914\left(\mathrm{TiO}_{2}\right.$ anatase). Puncak khas anatase terdapat pada $2 \theta 25^{\circ}, 38^{\circ}$, dan $48^{\circ}$. Penghalusan difraktogram partikel nano $\mathrm{TiO}_{2}$ dilakukan dengan metode Rietveld menggunakan program Rietica. Berdasarkan proses penghalusan, diperoleh nilai $x^{2}$ sebesar 1,186. Nilai $x^{2}$ yang mendekati 1 menunjukkan bahwa komposis hasil penghalusan mendekati nilai yang sebenarnya (Pratapa, 2007; Usman, 2015). Gambar 11 menunjukkan difraktogram XRD.

Gambar 11 menunjukkan puncak-puncak tertinggi difraktogram partikel nano $\mathrm{TiO}_{2}$ hasil sintesis cocok dengan puncak-puncak khas anatase pada ICSD standar. Partikel nano $\mathrm{TiO}_{2}$ baik dalam bentuk padatan maupun yang teremban pada kain katun memiliki fase anatase. Perhitungan ukuran kristal partikel nano $\mathrm{TiO}_{2}$ dilakukan dengan menghitung rata-rata ukuran kristal tiga puncak tertinggi $(25,314$; 38,193; dan 48,098) menggunakan pendekatan metode Scherrer. Ukuran kristal yang diperoleh adalah 14,05 nm. Ukuran kristal yang kecil menandakan luas permukaan yang besar. Maka, partikel nano $\mathrm{TiO}_{2}$ hasil sintesis baik dalam bentuk padatan maupun yang teremban pada kain katun, efektif untuk mendegradasi senyawa organik.

\section{KESIMPULAN}

Berdasarkan penelitian yang telah dilakukan, maka diperoleh simpulan:

1. Konsentrasi prekursor TTIP berpengaruh terhadap pengembanan partikel nano $\mathrm{TiO}_{2}$ pada kain katun. Semakin tinggi konsentrasi TTIP, semakin banyak massa partikel nano $\mathrm{TiO}_{2}$ yang ada pada kain katun. Metode sonokimia terbukti efektif untuk sintesis partikel nano $\mathrm{TiO}_{2}$ pada kain katun karena menghasilkan fase anatase dan ukuran yang kecil.

2. Terdapat perbedaan antara kemampuan selfcleaning katun- $\mathrm{TiO}_{2}$ pada radiasi sinar matahari dan pada radiasi lampu UV. Warna noda pada Katun- $\mathrm{TiO}_{2}$ lebih pudar setelah diradiasikan sinar matahari, dibandingkan dengan lampu UV. Maka sinar matahari cukup untuk memanfaatkan sifat self-cleaning pada katun- $\mathrm{TiO}_{2}$.

\section{DAFTAR PUSTAKA}

Pratapa, S. (2007). X-Ray Diffraction Phase Analyses for Granulated and Sintered Ceramic Materials. Makara Sains. 11(22): 85-89.

Qi, K., Daoud, W.A., Xin, J.H., Mak, C.L., Tang, W. \& Cheung, W.P. (2006). Self-cleaning cotton. Journal of Materials Chemistry. 16(47): 45674574.

Sadr, F.A. \& Montazer, M. (2014). In situ sonosynthesis of nano $\mathrm{TiO}_{2}$ on cotton fabric. Ultrasonics sonochemistry. 21(2): 681-691.

Usman, M.R. (2015). Pengaruh Variasi Pelarut Basa Terhadap Struktur dan Ukuran Kristal Titanium Dioksida $\left(\mathrm{TiO}_{2}\right)$ Hasil Sintesis Menggunakan Metode Hidrotermal. Tesis Magister. Universitas Padjadjaran, Bandung.

Wu, D., Long, M., Zhou, J., Cai, W., Zhu, X., Chen, C. \& Wu, Y. (2009). Synthesis and characterization of self-cleaning cotton fabrics modified by $\mathrm{TiO}_{2}$ through a facile approach. Surface and Coatings Technology. 203(24): 3728-3733 